NEW LITERARIA-

An International Journal of Interdisciplinary Studies in Humanities

Volume 1, No. 2, November-December, 2020, PP 70-77

ISSN- 2582-7375

DOI: https://dx.doi.org/10.48189/nl.2020.v01i2.011

www.newliteraria.com

\title{
Discourse on Gender Issues among Rural Women during Bodhgaya Land Struggle, Bihar, the late 1970s and 1980s
}

\author{
Upendra Kumar
}

\begin{abstract}
Bodhgaya land struggle was a unique agrarian struggle in the contemporary history of Bihar. Landless agricultural labourers led it under the leadership of Chhatra Yuva Sangharsh Vahini (CYSV) in the late 1970s and 1980s in the Gaya district of Bihar. The labourers demanded the right to the land which they had been tilling for long, but the Mahanths of Bodhgaya Math controlled the land. Apart from being an agrarian struggle, it was significantly a struggle of landless rural women who sought to redefine gender relations at the grassroots. The women tremendously participated in the struggle and seriously discussed the issues of women's right to land, gender division of housework, gender-based violence, and the institution of marriage during the period. The dialogues which happened among the women, including the women activists of the CYSV on gender issues were very crucial to comprehend the life of rural women. Thus, the paper aims to explore the discourse on gender issues in the context of the women's insistence on the redefinition of gender relations in rural areas. The paper equally highlights the women's issues, and notably limits itself to the gender dimension of the struggle. The significance of the paper is in attempting to explore the voices for redefining the gender relations that were coming from a highly marginalised section of the society in Bihar. To be sure, the women took the struggle as an opportunity to challenge the patriarchal attitude and unequal gender relations and envisaged gender equality.
\end{abstract}

Keywords: Gender Relations, Agrarian Struggle, Chhatra Yuva Sangharsh Vahini, Women's Right to Land, Bodhgaya Land Movement.

A momentous agrarian struggle occurred in the Gaya district of Bihar in the late 1970s and 1980s. The struggle was famously known as Bodhgaya land struggle which was led by landless agricultural labourers and sharecroppers under the leadership of Chhatra Yuva Sangharsh Vahini (CYSV), a youth organisation based on the Gandhian-socialist principles. The CYSV, whose chief patron was Jayaprakash Narayan, had been organising agrarian labouring classes in about 62 villages around Bodhgaya (Ahmed, 1980). The labourers and the sharecroppers fought against the Bodh Gaya Math whose Mahath had been controlling the large tracts of land, but the actual tillers of the land were agrarian labouring classes who had to cultivate the land under the various system of labour exploitation such as Kamia system and sharecropping. The Math did not give the tillers any receipt, so they were unable to claim their rights to the land under the sharecropping law (Manimala, 1983). Eventually, due to the Bodhgaya land struggle, about 8000 out of 12000 acres owned by the Math came under the control of the labourers and in four blocks of the Gaya District, namely Sherghati, Barachatti, Bodhgaya and Mohanpur, the struggle became relatively successful (Alaka \& 
Chetna, 1987).

During Bodhgaya land struggle, the rural proletariat women were equally mobilised by the CYSV to take part in the struggle against the Math of Bodhgaya for the land. Throughout, the mobilisation, the women activists immensely made efforts to aware of exploitative social structure and the patriarchal attitude of the society. The outstanding feature of the Bodhgaya land struggle had a clear-cut gender dimension, challenging unjust gender relations which legitimate subordination of the women in terms of agency and property rights. The women's participation was very conspicuous and high, and they were not only demanding control over the land, but also they resisted the gender-based violence and subordination to which they had to face because of being women. During the struggle, the women did not only keenly participate in demonstration and procession, but also they conversed and conveyed their issues and demands. Notably, the women made several arguments and dialogues which were generally related to their issues.

The discourse happened between the women activists of the CYSV and the rural women during the struggle opened up profound debates on women's issues like women's land rights, domestic violence and gender division of household work. As the women's participation in the Bodhgaya land struggle was very extraordinary and exciting, the women emphasised the potentiality of their participation. They underlined that without the women's involvement, any social transformation would be an unfinished task. One of the famous slogans of the struggle was "Aurat ke Sahbhag bina, har badlawa adhura hai" (without women's participation, any social transformation is incomplete, emphasize mine). It was a rallying slogan of the women during the struggle.

\section{Women's shivir}

The women activists of the CYSV organised women's shivir, which was the most vibrant grassroots camp where the gender issues were richly discussed among the women. In the shivir, the women discussed women's oppression and exploitation, discrimination against girls, men's verbal abuses against the women, domestic violence, women's need for independent land rights (Agarwal, 2002). Manimala (1983) mentioned a particular women's shivir that was organised by the activists-Kumud and Anjali for three days. In the shivir, there were several topics discussed cantered on gender issues such as:

what in the social set-up prevents the development of friendships between women, how women are downgraded through abusive language, how women are exploited by having to bear the total responsibility for housework, the way girls are discriminated against in the family, and why women are so caught up in ritualism. (Manimala, 1983, p. 9)

Indeed, the woman shivir provided a comfortable platform for the women to talk about their world view and for this reason "the women spoke freely about their personal oppression" in the shivir. In the concluding day of the shivir, in which around 500 women got gathered, several resolutions were passed, some of them were: (a) we suffer injustice both inside and outside the home, so we will have to fight for justice in both spheres; (b) men get drunk and then come and beat us, we will no longer tolerate this; (c) abuses are directed against "mothers" and "sisters"; we will neither use such abusive language nor tolerate its use; (d) women and men should have equal property rights, we will also demand our right to land (Manimala, 1983). The Shivir always attempted to integrate some other issues related to women such as the abduction of girls and channelizing them into prostitution, with the Bodhgaya land struggle. 


\section{Contested Definition of Antimjan}

From the beginning, the women activists opened up the discourse on gender issues. In a state meeting of the CYSV held in Patna on 17th- 18th January 1978, it was decided that the land struggle would be focused for antimjan (the last person), the most oppressed section of the society. The antimjan was described "as those who labour but at the same time do not exploit the labour of any individual or class" (Manimala, 1983, p. 2). According to this definition, the landless labourers were the focus of the struggle of the CYSV. The women activists made the definition contested as they contended that the definition had ignored the household labour which was exclusively performed by the women and exploited by the male member of the landless women labourers. So the definition did not legitimise the household labour as productive labour. Manimala who was an active women member of the CYSV, expressed that:

The organization was not sensitive enough to be able to acknowledge the significance of both types of exploitation [exploitation by landlords in the field and the exploitation of household work by menfolk of the women]. During our discussion, we stuck to a very worn out and conventional definition of labour, within which household labour has been given neither any economic nor any social value. (Manimala, 1983, p. 3)

\section{Women's Right to Land}

The active engagement of the women in the struggle made them more assertive and perceptive regarding gender relations, their rights and position in the society. The women activists increasingly felt the need to change the gender relations for any kind of transformative action for the women. They insisted on redefining gender relations based on the equal right to property between man and woman and firmly demanded women's right to land. Why land was so important for the women. Agarwal (2002) says that independent women's land right would empower the women economically and strengthen their ability to challenge social and political gender inequality. Furthermore, the women access to land can reduce household's risk of poverty and benefit not only women but also children.

The joint struggle of male and female landless agricultural labourers and poor peasants for land culminated in the identification of land for the distribution. In 1981, the government identified around 1000 acres of the Math's land, which were to be distributed among the struggling landless labourers (Agarwal, 2002). However, it became a debatable issue about the women's demand for independent right to land. The women had several rational and moral questions regarding the entitlement papers which were prepared by Mazdoor-Kisan Samiti of the CYSV for the distribution of land in the names of men and some widows. The women of Pesra village disappointedly said:

We were in the forefront of the fight, carrying our children in our wombs and in our arms. We went to jail and faced the lathis [sticks]; we also did all the housework. But when the land was distributed, we were pushed back; we didn't even come to know by what rules the land was distributed. (Manimala, 1983, p. 15)

The women's questions were "Why is the land to be distributed only in the names of men? Why are we excluded from any right to land? We are part of the struggle, so we should also get land in our owe names." They argued that "If the men who are today landless beat up their wives so badly, merely using the power derived from being men, then tomorrow with land in their possession, will they not become relatively even more powerful?" (Kelkar \& Gala, 1990, p.100). On 18 March 1981, in a village-level meeting, the women agricultural labourers demanded the right to land. Their demand shocked not only the male member of the 
Mazdoor-Kisan Samiti but also government officials.

The women's demand triggered a debate on the women's independent right to land. Arguments and counter-arguments emerged regarding the women's right to land and their capability and inability concerning ploughing the field. The male members of the Samiti remarkably perceived women's ability and inability under the patriarchal notion, predominantly gender division of labour and they contextualised and comprehended the women's demand under the ambit of the same notion. The male members of the Samiti argued that "Men have ploughed land since the known period of human history. And, that is why they are the owners of land." The women counter-argued that "Women sow the seeds and do most of the weeding, why can they not be owners of land?" (Kelkar \& Gala, 1990, p. 100). On the other hand, the women had already tried to defy the taboo on ploughing. In 1980, the CYSV's women collectively ploughed some land in Bija village, and in other villages, the women were ready to cultivate the land with hoes (Kelkar \& Gala, 1990, pp. 100-101).

The women castigated the patriarchal attitude of the CYSV during the Bihar State Conference of the Vahini held in Mehsi in East Champaran in 1982, and the women representative of Bodhgaya strongly demanded the right to land. They also reprimanded that the Vahini did nothing to include women in decision making. Ultimately, the state committee of the CYSV accepted the demand of the women but the major impediment to distribute land to the women in their independent names emerged from the local administration. The district and block-level government officials opposed women's independent right to land and categorically argued that it never happened earlier to give land to persons other than the heads of households, who were usually men (Agarwal, 2002). Nevertheless, the women kept arguing with the officials for their right to land. In this regard, the dialogues happened on 25 March 1982 between a woman of the village of Bija and a Circle Officer was a monumental argument in favour of women's right to land and gender equality. The dialogues between the woman and the officer are the following:

The officer: The law is to give land to the landless labourers.

The woman: Are we not the landless labourers?

The officer: Men plough the land. Will you women plough?

The woman: Do men transplant the rice? Do they sow the seeds? We too are the citizens of the country, and like the men have the right to vote.

The officer: What difference does it make to you, if your husband gets the land, and not you? If he has the land, you too, as his wife, have a share in it. Why do you oppose it?

The woman: We want our independent right to land. We do not ask for alms. Our struggle is for women's freedom and equality. We have been enslaved by men since ages. Now, we will not live in this enslaved condition.

The officer: If you persist and do not accept the man's ownership of the land, I will not distribute any land, I will not distribute any land at all.

The woman: We have taken a decision in the village that a title deed is not to be received unless it is in a woman's name. You may ask the men. If they disagree today, we will continue our struggle against them, too.

The officer: If we distribute land to the women, and then if a woman leaves her husband and marries another man, what then?

The woman: After marriage we have to apply sindoor. Our names are changed, the husband's names added to our names, while the men take their father's name. You should raise these questions when the land is given in the names of men. (Kelkar \& Gala, 1990, p. 102)

Ultimately, the land was distributed in Bija and Kusa village at an average of one acre of land per household in 1982. Around 1100 acres of land were distributed, but only 100 
acres of land were distributed in the names of women. It was very marginal. However it set an example that women can be landowners and possessed the land in their names that was not earlier heard as the officer had claimed, it was a step forward towards the recognition of the women's right to land. The local officials were still reluctant to distribute the land in the names of women. However, finally, the officials agreed to issue joint title to married couples. The joint ownership of land emerged as a movement. It was the result of the constant struggle of the women for their rights in land and gender equality. In 1987, about 5000 acres of land was distributed under the emerging notion of the joint ownership, the distributed land was registered in the joint names of husband and wife. Remarkably, the incidences to distribute land in the names of women could also be found, in December 1987, 65 acres of land in the Lebra village of Mohanpur block were distributed in the names of women (Kelkar \& Gala, 1990, p. 104). Some women were enthusiastic about getting land in their names as Alaka and Chetna (1987) recorded "Didi, earlier, we had tongues but could not speak; we had feet but could not walk. Now that we have got the land, we have got the strength to speak and to walk." (p.26)

\section{The Institution of Marriage as a Hierarchical Relation}

The institution of marriage had been a prominent subject to discuss among the women. The women activists of the CYSV raised several questions about the institution. They were firmly convinced that the institution of marriage had been a hierarchical relation between male and female and that relation subordinated woman in society. Furthermore, the women's subordination was predominantly justified by the gender roles which were organised in such a way which perpetuated the women's subordination. They did question not only the marriage institution but also monogamy, as these were the traditional-bound and hierarchical in nature, they restricted the freedom of the women and confined them behind the walls of the home. So the women believed that the sharing of sexual life with one's partner was 'a personal matter', (Kelkar \& Gala, 1990, p. 99) and advocated sexual freedom.

They also questioned the traditional way of marriage, such as kanya-daan and emphasised on simple marriages such as jaimala marriage in which the bride and groom garland each other in the presence of some friends and family members. They also encouraged inter-caste marriage and preferred registered marriage as some activities felt that in the jaimala marriage men seemed comparatively irresponsible in taking the responsibility of wife and children (Kelkar \& Gala, 1990, p. 99). The abandoning of some ritual forms of marriage such as kanyadan and stressing on the simple marriage such as jaimala were heavily debated among the women who gave their arguments in favour of simple marriage and against the idea of the repudiation of the traditional forms of marriage. In this regard, in a sammelan of 1980, a woman called Girija Devi strongly opposed the idea of discarding the traditional way of marriage and gave an argument that if a marriage happened without traditional rituals, men would be less likely to stick by women (Manimala, 1983). The women activists also argued about traditional symbols such as sindoor applied by women after marriage, bindi and toe-rings. They deemed the symbols as the identifier of subordination of the women in society.

\section{Household work}

The labouring class women in the rural area, apart from working as wage labourers in the field, they had to take entire domestic responsibilities of cooking, washing, childcare, serving their husbands. So the burden of the works on the head of the women was more than that of their menfolk. The household work, which had been traditionally assigned to women to fulfil, was vehemently debated during the Bodhgaya land struggle. In a village meeting of the 
activists of the CYSV in 1979, there was a discussion on the issues of the household work. It was a conviction that God had made women serve their husbands.

Nevertheless, it was argued that as both men and women worked in the fields so the load of household work could not be left on only women's heads. A male activist Anil Prakash put forward a suggestion that the men should do some household chores. The women had the same opinion on this. They ardently argued that since the women did harvesting, implanting, weeding and other works in the field, so why only the women did housework and look after children (Manimala, 1983). Ultimately, it was decided that the men would wash their plates after the meals. The discussion on the household chores was impactful as the women began to remark that from the day men should wash their plates.

Apart from the discussion, one of the remarkable incidences happened before the beginning of the meeting mentioned above. It would be pertinent to mention the incidence, here. In the meeting, a woman activist named Manimala of the CYSV made an argument on the sitting arrangement of the meeting. She observed that all the men were sitting on charpais while all women on the floor. She deliberately sat on the floor with the women. Both women and men asked her to sit on the charpai. When they emphasised it, she told that she would sit on the charpai only a condition that other women would also sit on the charpai. She also pressurised that if we could not sit together, we should discontinue the meeting. Eventually, the men got off the charpai and sat on the floor (Manimala, 1983). Positively, it was an attempt to make rural people particularly women, to understand the notion of equality, precisely gender equality. It was a simple way to realise how gender-based discrimination worked in day-to-day life.

\section{Wife Beating}

In the meeting described above, some of the village men justified wife beating and argued that they beat up their wives because their wives made mistakes and did not cook at the right time. The men also said that the wives did not listen to their husbands. Upon these men's arguments, the women in the meeting put forward counter-arguments. They contended whether the men never made mistakes and if they made mistakes whether they were beaten up for their mistakes by the women (Manimala, 1983). How to deal with the evil of wife beating was a major question before the women. The idea that those men who beat up their wife should not be allowed to join the CYSV or the meeting of the village committee was elaborately discussed among the women who also stressed that in the meeting only women would speak of the issues related to wife beating. Indeed, during the struggle, the woman activists attempted to stigmatise those who beat up their wives. The activists like Manimala declared that she would never sit and eat with a man who beat up his wife, and she also decided that she would not drink water from his hand. After her declaration, children began to report about the incidences of the wife beating. They began to expose their fathers and other men who beat up their wives.

The rural women were also aware of relation between domestic violence and land ownership. They perceived that the women's right to land would prevent the violence as they felt that if the land were distributed in the name of the men, they would beat up their wives more. So the getting right to land became a central goal of the women during the struggle. After the land distribution in the name of the women in Kusa and Beeja villages of Sherghati block of the Gaya district, Alaka and Chetna (1987) interviewed those women who got ownership in some lands. The women confidently told that "Didi, the men cannot so easily throw us out of the house now. They are afraid lest if they trouble us too much and we leave, the land too will go with us and they will get nothing." (p. 26) 


\section{Habits of Drinking Liquor}

The drinking habits of a person might not be directly linked with the gender issue. However, during the Bodhgaya struggle, the drinking habits of the menfolk of the rural women became one of the leading concerns to be addressed, because the alcoholism inevitably led domestic violence against women in the rural area. In 1979, a nine-year old girl in a village meeting of the CYSV reported an evening that her drunken father badly beat up her mother because of the refusal of her mother to sleep with her drunken father (Kelkar and Gala, 1990, p. 97). This incident evoked a debate on the connection between domestic violence and the drinking habit of men. It was also reported that the wives were beaten up when they refused to give money to their men for drinking alcohol. So the men's drinking habits became oppressive for the women, and also it increased the financial burden of the household on the women's shoulder as the men's earning, not whole but at least some part of the earning was spent on the drinking. So the discussion on the men's drinking habits and campaign against it became a subject of the Bodhgaya struggle. Kumud and Kanchan, women activists of the CYSV, took responsibility to lead the campaign against alcoholism; apart from the women, the village's children also played a significant role in the campaign (Manimala, 1983). In several meetings held in various villages for the discussion on the issue. Why did the men drink alcohol? Why should the men stop it? Why was liquor wrong? How should the habit be stopped? What was the relation between alcoholism and domestic violence? These were some of the questions which were debated among the rural women.

\section{Conclusion}

The struggle was significantly a struggle of landless rural women who sought to redefine gender relations. They contended the existing hierarchical gender relations in the terms of the right to land and passionately emphasised on gender equality in the distribution of land. Most importantly, the women were attempting by putting forward several arguments to dispose of the patriarchal system in their home. They made the institution of marriage a contested institution, as according to them, it was based on unequal gender relations and subscribed the subordination of women. In a nutshell, during the Bodhgaya struggle, the women got engaged in the debates on gender equality, gender relations and domestic violence. They resisted the women subordination and patriarchal attitude of the society.

\section{References}

Agarwal, B. (2002). Are we not peasants too? Land rights and women's claims in India. Seeds, (21), 1-30.

Ahmed, F. (1980, December 15). Labourers demand share to the crops grown on landed property held by Bodhgaya Mahant. India Today. https://www.indiatoday.in/magazine/indiascope/story/19801215-labourers-demandshare-to-the-crops-grown-on-landed-property-held-by-bodhgaya-mahant-7736392013-11-30

Alaka \& Chetna. (1987). When women get land- A report from Bodhgaya. Manushi, (40), 25-26.

Kelkar, G. \& Gala, C. (1990). The Bodhgaya land struggle. In Ilina Sen (Eds.), A space within the struggle: Women's participation in people's movements, pp. 82-110. Kali 
for Women.

Kelkar, G. (n.d.). Poor Peasant women organize for land rights. Canadian Women Studies, 13 (1), 69-75.

Manimala. (1983).'Zameen kenkar? Jote onkar! The story of women's participation in the Bodhgaya land struggle. Manushi, (14), 2-16, January-February.

\section{Bio-note}

Upendra Kumar is a Ph.D. Scholar at Dr. K. R. Narayanan Centre for Dalit and Minorities Studies, Jamia Millia Islamia (JMI), New Delhi. He is also teaching undergraduate students as a Guest Faculty at the University of Delhi. He completed his M.Phil. in 2016 from the JMI and M.A. in History, specialisation in Modern History from Banaras Hindu University, Varanasi, and cleared UGC- NET and JRF. His research interests lie primarily in the area of agrarian struggles, caste, class, and gender.

Email id: upendrakumar200884@gmail.com 